\title{
Adult plant resistance to stem rust (Puccinia graminis f. sp. tritici) in Pakistani advanced lines and wheat varieties
}

M.U. Rehman ${ }^{1}$, S. Gale ${ }^{2}$, G. Brown-Guedira ${ }^{3}$, Y. Jin $^{2}$, D. Marshall ${ }^{3}$, L.W. Whitcher ${ }^{3}$, S. Williamson ${ }^{3}$, M. Rouse $^{2}$, S. Bhavani ${ }^{4}$, M. Hussain ${ }^{6}$, G. Ahmad ${ }^{7}$, M. Hussain ${ }^{8}$, M.A. Sial ${ }^{9}$, J.I. Mirza ${ }^{10}$, Y. Rauf ${ }^{1}$, A.R. Rattu ${ }^{11}$, M. Qamar $^{12}$, K.A. Khanzada ${ }^{13}$, A. Munir ${ }^{14}$, R. Ward ${ }^{1}$, R. Singh ${ }^{5}$, H. Braun ${ }^{5}$ and M. Imtiaz ${ }^{1 *}$

${ }^{1}$ International Maize and Wheat Improvement Center (CIMMYT) Pakistan Office, CSI Building, NARC, Park Road, Islamabad 44000, Pakistan

${ }^{2}$ USDA-ARS, Cereal Disease Laboratory, University of Minnesota, St. Paul, MN, USA

${ }^{3}$ USDA/ARS-Plant Science Research Unit 3411 Gardner Hall Box 7616, North Carolina State University, Raleigh, NC 27695-7616, USA

${ }^{4}$ International Maize and Wheat Improvement Center (CIMMYT) Kenya

${ }^{5}$ International Maize and Wheat Improvement Center (CIMMYT), Mexico

${ }^{6}$ Wheat Research Institute, AARI Faisalabad, Punjab, Pakistan

${ }^{7}$ Cereal Crop Research Institute (CCRI), Pirsabak, KPK, Pakistan

${ }^{8}$ Regional agricultural research institute (RARI), Bahawalpur Pakistan

${ }^{9}$ Nuclear Institute of Agriculture (NIA), Tandojam, Pakistan

${ }^{10}$ Crop Diseases Research Institute, Murree, Pakistan

${ }^{11}$ Pakistan Agricultural Research Council (PARC), Islamabad, Pakistan

${ }^{12}$ Crop Sciences Research Institute Wheat Program, NARC-Islamabad, Pakistan

${ }^{13}$ Crop Diseases Research Institute, Karachi, Pakistan

${ }^{14}$ Crop Diseases Research Institute, NARC, Pakistan

\section{*Correspondence author: m.imtiaz@cgiar.org}

Abstract

After decades of effective wheat stem rust control, due mainly to use of the Sr31 resistance gene in wheat, as of the early 2000 s new virulent strains of the stem rust fungus, especially the Ug99 or the TTKSK races, are spreading and overcoming the resistance of commercial varieties worldwide, including the Sr24 and Sr36 resistance genes in Kenya. To address this, researchers are working to identify new resistance sources and to develop and release new high-yielding, resistant and adapted varieties. In this study we evaluated 707 advanced spring wheat lines and varieties for adult plant resistance (APR) to stem rust at the Njoro research station of the Kenya Agricultural \& Livestock Research Organization, using a modified Cobb's scale, and for seedling resistance at the Cereal Disease Laboratory (CDL), University of Minnesota, using the 0-4 Stakman et al. (1962) scale. We found 101 lines that showed APR and, through molecular marker analysis, identified 18 lines carrying the stem rust resistance marker allele for the Sr25/Lr19 gene. Of these 18 lines, 11 were resistant to Ug99 at both the seedling and adult stages and 7 were susceptible at the seedling stage, showing infection type (IT) 3 to 4 , and moderately susceptible at the adult plant stage. Another 20 lines were resistant at all stages of development, without Sr25/Lr19 marker allele indicated the possibility of carrying other genes for stem rust resistance. We shared the results with national program breeders and scientists in Pakistan to facilitate the use of resistant lines in crossing programs and enhance stem rust resistance in candidate wheat varieties. As a result number of lines resistant to Ug99/ and its variants (TTKSK, TTKST) have been identified and released as commercial varieties, including NR-397 (Pakistan-2013) and NR-356 (NARC-2011).

Keywords: Disease severity; Race non-specific resistance; Triticum aestivum; Ug99; wheat rust.

Abbreviations: APR_Adult Plant Resistance, BRS_Baseline Resistance Study, CDL_Cereal Disease Laboratory, University of Minnesota, CIMMYT_International Maize and Wheat Improvement Center, Mexico, IT_Infection Type, MR_Moderately Resistant MRMS or M_Moderately Resistant-Moderately Susceptible or Moderate responses. MS_Moderately Susceptible, MSS_Moderately Susceptible to Susceptible, Pgt_Puccinia graminis f. sp. Tritici, RMR_Resistant to Moderately Resistant, S_Susceptible, USDA-ARS_ United State Department of Agriculture, Agricultural Research Service, WPEP_Wheat Production Enhancement Program.

Introduction

Wheat stem rust (Puccinia graminis f. sp. tritici, Pgt) had largely been controlled from the late 1970s due to the widespread use of host-plant resistance and the elimination of the alternate host Berberis spp. in North America and 
Europe. In 1999, a new virulent race of Pgt was confirmed in Uganda (Pretorius et al., 2000) named isolate Ug99 and later designated as race TTKSK (Jin et al., 2008; Wanyera et al., 2006). Ug99 was unique due to its virulence on the widely deployed stem rust resistance gene, Sr31. Variants of Ug99 have spread throughout eastern and southern Africa, Zimbabwe, Sudan, Yemen and Iran (Nazari et al., 2009; Pretorius et al., 2010; Singh et al., 2006) and was most recently reported in Egypt (Patpour et al., 2016). Some Ug99 variants are able to overcome the resistance based on $\mathrm{Srgh}$, Sr24, Sr36 and SrTmp (Jin et al., 2008; Jin et al., 2009; Newcomb et al., 2016; Rouse et al., 2011). Stem rust could cause severe yield losses if the new races migrate to major wheat producing regions in South Asia, especially in India and Pakistan, where it has not yet been reported. The migratory route for variants of the stripe rust pathogen, Puccinia striformis, was shown to go from Africa to Asia (Singh et al., 2004, 2011); stem rust may follow same pattern.

The major-effect, seedling resistance gene $S r 31$ provided protection from stem rust for almost three decades, but major-effect genes can be overcome by new virulences in the Pgt population in as little as 3 to 4 year (Singh and Rajaram, 1992; Singh et al., 2000). Conversely, racenonspecific adult plant resistance (APR) genes with additive minor effects can be combined to enhance durability for resistance. Genetic studies conducted at International Maize and Wheat Improvement Center (CIMMYT) have shown that $A P R$ in its wheat lines derives from combinations from among 12 different genes (Bhavani et al., 2011). By accumulating 4-5 minor resistance genes, resistance levels approaching immunity can be achieved and combinations of 2-3 genes provide moderate levels of resistance (Singh et al., 2005, 2009). Studies have characterized APR genes Sr55, Sr57 and Sr58, which confer pleiotropic effects for diseases such as leaf rust, stripe rust and powdery mildew, and $\mathrm{Sr} 2 / \mathrm{Yr} 30$, which associated with resistance to stem rust and to pseudo black chaff (Hare and McIntosh, 1979; HerreraFoessel et al., 2014; Rosewarne et al., 2006; Singh, 1992). International collaborations have quickly and effectively screened wheat germplasm for new sources of stem rust resistance (Jin and Singh, 2006; Njau et al., 2010). To protect and enhance the productivity of wheat in Pakistan, United State Department of Agriculture (USDA) and CIMMYT partnered under the Wheat Production Enhancement Program (WPEP) to characterize Pakistani wheat germplasm, including advanced breeding lines and commercial varieties, for resistance to the Ug99 race group. The objectives of this research were to assess the APR to stem rust against Ug99 resistance in Pakistani wheat germplasm/varieties, identify sources of resistance and promote their use in national wheat breeding programs.

\section{Results and discussion}

Spring wheat breeding lines and varieties were evaluated for seedling reactions at the $\mathrm{CDL}$ and displayed a range of infection types to the Pgt race TTKSK. Lines carrying the marker linked to the gene Sr25/Lr19 and infection type data against the races TTKSK and TTKST are given in Table 1. Race TTKSK was virulent to $86 \%$ of the tested lines. We identified lines that were resistant both as seedlings and in the field. These included both released varieties and advanced lines (Table 2), which confirmed that lines with seedling resistance remained resistant when tested in the field, as previously reported (Kumssa et al., 2015). The low infection responses recorded in the field for seedling resistant lines may be due to the hypersensitive reaction, as reported elsewhere (Rubiales and Nicks, 2000).

\section{Responses of lines carrying marker allele linked with gene Sr25}

Based on molecular marker data, the lines postulated to possess the $\mathrm{Sr} 25$ gene are listed in Table 1. Infection type data for the lines with marker detected stem rust resistance gene $S r 25 / L r 19$ indicated that 7 of the lines were susceptible (IT > 2) to race TTKSK (NR-379, SD-5, NR-421, V-10317, V3007, DN-92 and Imdad-05). We are unsure of the susceptibility of lines carrying Sr25, as TTKSK is considered avirulent to Sr25 (Jin et al., 2008). The disagreement between phenotype and genotype could be attributed to (1) a false-positive, as the linked marker(s) used are probably not diagnostic for the gene(s); (2) false-susceptible infection types, especially for Sr25, which has an intermediate infection type; or (3) the heterogeneity of the lines. This also provides information on the effectiveness of using molecular markers to predict phenotypes. Two of these 7 lines (NR-421 and DN-92) were moderately susceptible at the adult stage with a severity of up to $30 \%$, whereas lines V-10317 and V3007 were moderately susceptible to susceptible (MSS), with $15 \%$ and $20 \%$ severity values respectively. Responses moderately resistant (MR) and resistant to moderately resistant (RMR) were observed for the lines NR-379 and SD5 , with severities of $20 \%$ and $10 \%$ respectively. Line Imdad05 showed a moderate response, with $40 \%$ rust severity. The rest of the 11 lines carrying Sr25 gene were resistant to stem rust at both the seedling and adult plant stages. When tested for seedling resistance against TTKST, these lines also showed resistant infection types (Table 1), indicating they are potentially useful sources of resistance.

\section{Field screening for adult-plant resistance (APR) in Kenya}

Adult plant resistance is a useful trait for varietal selection. The Njoro field site is considered a hot spot for stem rust infection and artificial epidemics were created to ensure high disease pressure to evaluate wheat lines. Field screening of the baseline resistance study sets revealed a diversity of infection responses and severities. All types of host reactions and their combinations were observed, ranging from $\mathrm{R}$ to $\mathrm{S}$ types of infection response, whereas severity values in the field ranged from 0 to $100 \%$.

Many of the lines tested were highly susceptible (70S-100S) in the field, showing high disease pressure, which was also evident from the response of susceptible check (Table 3 ). Similarly, some of the lines tested rusted slowly at the beginning but reached terminal severities of over $70 \%$ (data 
Table 1. Responses of wheat lines carrying Sr25 linked-marker allele both at seedling and adult plant stage.

\begin{tabular}{|c|c|c|c|c|c|c|c|}
\hline \multirow[b]{2}{*}{ No. } & \multirow{2}{*}{ Nomenclature $^{1}$} & \multirow[b]{2}{*}{ Parentage } & \multirow{2}{*}{\multicolumn{2}{|c|}{$\mathrm{IT}^{2}$ to race }} & \multicolumn{2}{|c|}{$\begin{array}{l}\text { APR-Kenya, 2011-13 } \\
\text { severity }\end{array}$} & \multirow{2}{*}{$\begin{array}{l}\text { Other SR } \\
\text { gene }\end{array}$} \\
\hline & & & & & $\begin{array}{l}\text { severity } \\
(0-100)\end{array}$ & $F R^{3}$ & \\
\hline 1 & NR-356(NARC-11) & OASIS/SKAUZ//4*BC/3/2*PASTOR & 2 & $2-$ & 5 & MSS & $\mathrm{Sr} 2$ \\
\hline 2 & NR-379 & WHEAR//2*PRL/2*PASTOR & 3 LIF & 3 & 20 & $\mathrm{MR}$ & - \\
\hline 3 & NR-378 & WHEAR//INQALAB91*2/TUKURU & 2 & 2 & 15 & MS & - \\
\hline 4 & NR-392 & WHEAR/SOKOLL & 2 & $2-/ 3$ & 10 & RMR & $\operatorname{Sr} 2$ \\
\hline 5 & NR 410 & SOKOLL/3/PASTOR//HXL7573/2*BAU & $2+$ & $2+$ & 10 & MSS & - \\
\hline 6 & NR 389 & KRICHAUFF/2*PASTOR & $2-/ 4$ & NT & 10 & MSS & $\begin{array}{l}\text { Sr24/Lr24, } \\
\text { Sr2 }\end{array}$ \\
\hline 7 & NR 395 & OASIS/SKAUZ//4*BCN/3/2*PASTOR & $2-;$ & 2 & 10 & $\mathrm{R}$ & \\
\hline 8 & SD-5 & VASCO $\times$ TJ-83 & 3 LIF & 3 & 10 & RMR & Sr24/Lr24 \\
\hline 9 & NR 421 & $\begin{array}{l}\text { CROC_1/AE.SQUARROSA210)//INQALAB91*2/KUK } \\
\text { UNA/3/PBW343*2/KUKUNA }\end{array}$ & 3 & NT & 30 & MS & - \\
\hline 10 & B-1 (RF)- 11 & CHEWINK & 2 & $2 / 3$ & 20 & $\mathrm{MR}$ & - \\
\hline 11 & $11 \mathrm{C022}$ & SOKOLL//SUNCO/2*PASTOR & $2-$ & $2+$ & 20 & MSS & Sr24/Lr24 \\
\hline 12 & CCRI-1 & OR 9437534/SOKOLL//SOKOLL & $0 / 23-$ & $2+/ 3$ & 10 & M & Sr9a \\
\hline 13 & CCRI-2 & $\begin{array}{l}\text { MTRWA92.161/PRINIA/5/SERI*3//RL6010/4*YR/3/ } \\
\text { PASTOR/4/.... }\end{array}$ & $23-$ & $2+$ & 40 & M & - \\
\hline 14 & CCRI-4 & BERKUT/EXCALIBUR & 2 & 2 & 30 & M & - \\
\hline 15 & V-10317 & $\begin{array}{l}\text { CHRZ//BOW/CROW/3/WBLL1/4/CROC_1/AE.SQUA } \\
\text { RROSA(213)//PGO }\end{array}$ & $3+$ & NT & 15 & MSS & - \\
\hline 16 & V3007 & CHIR3/4/SIREN/ALTAR84/ - - - - - & 4 & NT & 20 & MSS & - \\
\hline 17 & DN-92 & $\begin{array}{l}\text { CROC_1/AE.SQUARROSA(224)//OPATA/3/KAUZ*2 } \\
\ldots\end{array}$ & 4 & NT & 10 & MS & - \\
\hline 18 & Imdad-05 & CHIL/2*STAR & $3+$ & NT & 40 & M & - \\
\hline
\end{tabular}

${ }^{1}$ Nomenclature were based on the breeder coded number
${ }^{2} \mathrm{IT}=$ Infection types where $0, ;, 1,2$, or combinations were considered low infection types (resistant), and 3 to 4 were considered high infection types (Stakman et al., 1962).

LIF- Low Infection Frequency.

NT- Not Tested

Table 2. Wheat lines with both seedling and field resistance to stem rust Ug99.

\begin{tabular}{|c|c|c|c|c|}
\hline No. & Nomenclature & Parentage & $\begin{array}{l}\text { Seedling IT } \\
\text { at CDL }\end{array}$ & $\begin{array}{l}\text { Kenya SR Field } \\
\text { data }\end{array}$ \\
\hline 1 & Jauhar-78 & NAYAB*(Fast Neutron 600 Rads) (Mutant Variety) & 2 & 40MR \\
\hline 2 & NR-356 & OASIS/SKAUZ//4*BC/3/2*PASTOR & 2 & $20 \mathrm{M}$ \\
\hline 3 & NR-398 & TC870344/GUI//TEMPORALERA87/AGR/3/2*WBLL1 & $2+3$ & $10 \mathrm{M}$ \\
\hline 4 & NR-407 & $\begin{array}{l}\text { UP2338*2/VIVITSI/3/FRET2/TUKURU//FRET2/4/OASIS/SKAUZ//4*BCN/3/2 } \\
\text { *PASTOR }\end{array}$ & 2- & $5 \mathrm{M}$ \\
\hline 5 & CCRI-10 & WON-D 22/HUBARA-13 & $2 / 3+$ & $10 \mathrm{M}$ \\
\hline 6 & CCRI-11 & FIDIYA-23 & 2 & $20 \mathrm{M}$ \\
\hline 7 & V-08082 & V-87094/2*PAK81//SHAFAQ-06 & $2+$ & $10 \mathrm{M}$ \\
\hline 8 & V-08118 & MILAN/S 87230//BABAX & $2+3$ & $15 \mathrm{MS}$ \\
\hline 9 & V-10309 & SOONOT-10 & $2-$ & $5 \mathrm{MR}$ \\
\hline 10 & V3010 & BABAX/LRUZ//2/4/SNI/TRAP\#1/3/KAUZ*2/ - - & $22+$ & $15 \mathrm{M}$ \\
\hline 11 & V3019 & SW89.5277/BORL//SKAUZ & $2+3$ & $10 \mathrm{MS}$ \\
\hline 12 & V-06BT005 & FSD.-85/UFAQ-02/2/SH-02/3/CROW'S & $2+3$ & $15 \mathrm{MS}$ \\
\hline 13 & 09FJ21 & 99FJ03/PAK-81 & $0 ; 1+$ & $10 \mathrm{M}$ \\
\hline 14 & 09FJ34 & ERAF2000/4/FONCHAN\#3/TRT'S'//VEE\#9/3/COOK/VEE'S'//DOVE'S'/SERI & $0 / 3$ & $5 \mathrm{MS}$ \\
\hline 15 & 99174 & - & $2+3$ & $10 \mathrm{M}$ \\
\hline 16 & 11B2024 & PFAU/MILAN/3/SKAUZ/KS94U215//SKAUZ & 0 & 20RMR \\
\hline 17 & 11B2057 & HUW234+LR34/PRINIA*2//WHEAR & 2 & 40MR \\
\hline 18 & B-2 (RF)- 11 & SOONOT-10 & $2 / 3$ & $15 \mathrm{MR}$ \\
\hline 19 & B-2 (RF)- 17 & TOB/ERA//TOB/CNO67/3/PLO/4/VEE\#5/5/KAUZ/6/... & 1 & $30 \mathrm{M}$ \\
\hline 20 & $\mathrm{~B}-3$ (RF)- 19 & PFAU/MILAN/3/SKAUZ/KS94U215//SKAUZ & 2 & 20MR \\
\hline
\end{tabular}


Table 3. Adult plant resistance in wheat lines for stem rust - Kenya 2011-13.

\begin{tabular}{|c|c|c|c|c|c|}
\hline Nomenclature & Seedling data & APR-Kenya & Nomenclature & Seedling IT & APR-Kenya \\
\hline Bahawalpur-97 & $3+$ & $30 \mathrm{M}$ & V3027 & 4 & $10 \mathrm{M}$ \\
\hline Ghaznavi & $3+$ & $30 \mathrm{M}$ & V3031 & 4 & $15 \mathrm{MS}$ \\
\hline Punjab 81 & 4 & $20 M$ & V3032 & 4 & $15 \mathrm{MS}$ \\
\hline Barani-70 & 4 & $20 \mathrm{M}$ & V3033 & $3+$ & $15 \mathrm{MS}$ \\
\hline Sandal & 3 & $40 M R$ & V-9407 & 3 & $10 \mathrm{M}$ \\
\hline SA 75 & 4 & $30 \mathrm{M}$ & NR-400 & 4 & $15 \mathrm{M}$ \\
\hline D-97 & 4 & $30 M$ & $V-7 / 2011$ & 4 & $20 \mathrm{M}$ \\
\hline NR-333 & 4 & $20 \mathrm{M}$ & NRL-0707 & $3+$ & $15 \mathrm{MS}$ \\
\hline V-029221 & $33+$ & $30 \mathrm{M}$ & AUP-1052 & 4 & $10 \mathrm{MS}$ \\
\hline NR-333 & 3 & $30 M$ & AUR-0809 & 4 & $10 \mathrm{MS}$ \\
\hline $11 C 018$ & $3+$ & $10 \mathrm{M}$ & AUP-1059 & $3+$ & $10 \mathrm{M}$ \\
\hline 11C019 & $3+$ & $10 \mathrm{MS}$ & NR 371 & 4 & $15 \mathrm{M}$ \\
\hline $\mathrm{DH}-31$ & $3+$ & $5 \mathrm{MR}$ & NR-394 & 4 & $10 \mathrm{MS}$ \\
\hline BARS-09 & $3+$ & $15 \mathrm{MS}$ & NR-402 & $3+$ & $5 \mathrm{M}$ \\
\hline PR-102 & $3+$ & $0,5 R$ & NR-404 & $3+$ & $5 \mathrm{M}$ \\
\hline MPT (N)- 8 & 4 & $10 \mathrm{M}$ & NR-405 & 3 & $5 M$ \\
\hline MPT (N)- 13 & $3+$ & $10 \mathrm{MS}$ & NR-406 & $3+$ & $5 \mathrm{M}$ \\
\hline MPT (N)- 29 & 3 & $10 \mathrm{M}$ & NR-408 & $3+$ & $5 M$ \\
\hline MPT (RF)-2 & $3+$ & $10 \mathrm{M}$ & NR-409 & 4 & $5 \mathrm{M}$ \\
\hline MPT (RF)-9 & 4 & $15 \mathrm{M}$ & NR 413 & $3+$ & $10 \mathrm{M}$ \\
\hline AAS 2011 & 3 & $5 \mathrm{MS}$ & NR 415 & 4 & $5 \mathrm{MS}$ \\
\hline 11212 & 3 & $5 \mathrm{M}$ & NR 417 & $3+$ & $10 \mathrm{MS}$ \\
\hline 11213 & $3+$ & $10 \mathrm{M}$ & NR 418 & 4 & $10 \mathrm{MS}$ \\
\hline 11214 & $3+$ & $15 \mathrm{M}$ & SUSSUI & $3+$ & $15 \mathrm{M}$ \\
\hline 11215 & 3 & $10 \mathrm{M}$ & V-10035 & 3 & $10 \mathrm{M}$ \\
\hline 11280 & 3 & $15 \mathrm{M}$ & 11B2049 & $3+$ & $20 \mathrm{M}$ \\
\hline 11282 & $3+$ & $25 \mathrm{MS}$ & NR 402 & $3+$ & $10 \mathrm{MS}$ \\
\hline V-08171 & 3 & $5 \mathrm{MS}$ & NR 405 & 3 & 10RMR \\
\hline V-08211 & $3+$ & $5 \mathrm{MS}$ & NR 406 & 3 & $10 \mathrm{M}$ \\
\hline V-08212 & $3+$ & $10 \mathrm{MS}$ & $15-03$ & $3+$ & $20 \mathrm{M}$ \\
\hline V-08314 & $3+$ & $20 \mathrm{MS}$ & AYT (2011-12) 29 & 3 & $20 M$ \\
\hline V-10306 & 4/; & $15 \mathrm{M}$ & MPT (N)- 7 & $3+$ & $20 \mathrm{M}$ \\
\hline 09FJ09 & $3+$ & $20 \mathrm{M}$ & PR-98 & $3+$ & $20 \mathrm{MS}$ \\
\hline 09FJ33 & 3lif & $5 \mathrm{MS}$ & NIA-MN-8 & $3+$ & $20 M R$ \\
\hline 06FJS3013 & $3+$ & $10 \mathrm{MS}$ & PR-104 & 3 & $30 \mathrm{M}$ \\
\hline 08FJ97 & 3 & $10 \mathrm{MS}$ & V-107 (NR-310) & 3 & $30 \mathrm{M}$ \\
\hline Mairaj-08 & 4 & $10 \mathrm{M}$ & V-112 (V-11164) & 3 & $30 \mathrm{M}$ \\
\hline 10B9913 & 4 & $10 \mathrm{M}$ & V-117 (10BT002) & $3+$ & 15RMR \\
\hline 6422 & 4 & $10 \mathrm{MS}$ & V-120 (V-10193) & $3+$ & $20 \mathrm{M}$ \\
\hline 99115 & $3+$ & $10 \mathrm{MS}$ & $11 \mathrm{C} 023$ & $3+$ & $20 M$ \\
\hline 76346 & $3+$ & $10 \mathrm{M}$ & V-11168 & 4 & $20 \mathrm{M}$ \\
\hline 10B-9346 & 4 & $10 \mathrm{MS}$ & AZRC-5 & $3+$ & $20 \mathrm{MS}$ \\
\hline 10B-9369 & $3+$ & $10 \mathrm{M}$ & CCRI-24 & $3 \mathrm{LIF}$ & $30 \mathrm{M}$ \\
\hline 10B-9370 & $3+$ & $15 \mathrm{M}$ & CCRI-28 & $3+$ & $30 \mathrm{M}$ \\
\hline 10B-9381 & $3+$ & $10 \mathrm{MS}$ & AZRC-12 & $3+$ & $40 \mathrm{MR}$ \\
\hline 10B-9383 & $3+/ 2$ & $10 \mathrm{M}$ & AZRC-15 & $3+$ & $15 \mathrm{M}$ \\
\hline V3013 & 4 & $10 \mathrm{M}$ & AZRC-16 & $3+$ & 20RMR \\
\hline V3014 & 4 & $15 \mathrm{MS}$ & AZRC-17 & $3+$ & 10RMR \\
\hline V3015 & 4 & $15 \mathrm{MS}$ & AZRC-30 & $3+$ & $20 \mathrm{M}$ \\
\hline V3020 & 4 & $10 \mathrm{MS}$ & V3025 & 4 & $20 \mathrm{M}$ \\
\hline V3023 & 4 & $10 \mathrm{M}$ & Check & 4 & $100 \mathrm{~S}$ \\
\hline
\end{tabular}


Table 4. Wheat lines with seedling resistance to Ug99 and susceptible at adult plant stage.

\begin{tabular}{|c|c|c|c|}
\hline Nomenclature & Parentage & Seedling IT & Kenya field score \\
\hline Khyber 87 & KVZ/TRM//PTM/ANA & ;2-3 & 50MSS \\
\hline HB-10 & CHEN/AEGILOPS SQUARROSA (TAUS)//BCN/3/VEE\#7/... & $2+$ & $70 \mathrm{M}$ \\
\hline NRL-0517 & PASTOR/3/ALTAR84/AEGILOPS SQUARROSA(TAUS)//OPATA (SOKOLL) & $2+$ & 50MSS \\
\hline TW96007 & XIANG 820261x2-KAUZ/MILVUS & $2+$ & $40 \mathrm{M}$ \\
\hline NR-383 & $\begin{array}{l}\text { MUNIA/CHTO/3/PFAU/BOW//VEE\#9/4/CHEN/AEGILOPS SQUARROSA } \\
\text { (TAUS)//BCN/5/BABAX/LR42//BABAX }\end{array}$ & $2-;$ & $90 \mathrm{~S}$ \\
\hline NR-389 & KRICHAUFF/2*PASTOR & 2- & 40MSS \\
\hline 11C021 & SOKOLL/EXCALIBUR & ;2- & 30MSS \\
\hline MPT (N)- 19 & PVN//KAUZ/PVN/3/PS-85 & $2-;$ & 40MSS \\
\hline 11235 & WATTAN/FSD//KRITATI & $2+3$ & 30MSS \\
\hline V-09087 & V-87094/2*INQ.91/3/SH88/PAK81/MH97 & 2lif & 40MSS \\
\hline WL-08109 & SALEEM 2K / HD-2169 & $2,3+$ & $25 \mathrm{MSS}$ \\
\hline 99108 & CHEN/AE.SQ & $2-$ & $25 \mathrm{MSS}$ \\
\hline V3008 & CHIR3/4/SIREN//ALTAR84/ - - - & ;3+lif & 40MSS \\
\hline V3022 & HUW234+LR34*2/PASTOR & $2 / 4$ & $25 \mathrm{MSS}$ \\
\hline NR-399 & SOKOLL/3/PASTOR//HXL7573/2*BAU & $2+$ & 30MSS \\
\hline V-10014 & V-00125 / INQLAB-91 & $2 / 3$ LIF & $70 \mathrm{M}$ \\
\hline 11B2058 & HUW234+LR34/PRINIA*2//KIRITATI & 2 & $60 \mathrm{M}$ \\
\hline 11B2106 & CB208/CB175 & $2 / 3$ LIF & $60 \mathrm{MSS}$ \\
\hline 11050 & ZEMAMMRA-1/5/HAHN/2*WEAVER/4/BOW/CROW//BUC/PVN/3/2* VEE \# 10 & 2 & $60 \mathrm{M}$ \\
\hline 11079 & SOVA/4/MILAN/3/JUP/BJY//URES & $2 / 3$ & $60 \mathrm{~S}$ \\
\hline 11092 & KANCHAN/AUQAB-2000//AS-2002 & 2 & $60 \mathrm{M}$ \\
\hline NRL 0902 & PASTOR/WBLL1 & 2 & $40 \mathrm{M}$ \\
\hline NR 407 & UP2338*2/VIVITSI/3/FRET2/TUKURU//FRET2/4/OASIS/SKAUZ//4*BCN/3/2*PASTOR & $0 / 3$ LIF & $60 \mathrm{MSS}$ \\
\hline IEYT(2011-12) 10 & ABUZIG-11/CHAN-8/Fret-2/FRET2*2/BRAMBLING & 2- & $60 \mathrm{M}$ \\
\hline IEYT(2011-12) 40 & AUQAB-2000/WBLL1*2/BRAMBLING & ;13/4 & $60 \mathrm{MSS}$ \\
\hline$B-1(N)-6$ & PBW343*2/KUKUNA*2//YANAC & $0 ; / 3$ & $60 \mathrm{MSS}$ \\
\hline B-1 (RF)- 12 & CHEN/AEGILOPS SQUARROSA (TAUS)//BCN/3/BAV92/4/BERKUT... & $0 / 3$ & $60 \mathrm{MSS}$ \\
\hline B-2 (RF)- 19 & PASTOR/WBLL1 & 0 & 60MSS \\
\hline NN-Gandam-2 & WEEBIL/4/SABUF*2//PAVON 76/3/MH97 & $0 / 3+$ & $70 \mathrm{~S}$ \\
\hline SD-998 & TJ-83 $\times 4085 / 3$ & ; & $60 \mathrm{M}$ \\
\hline V-106 (V-11156) & PSN/BOW//MILAN/3/2*BERKUT & ;2- & $60 \mathrm{~S}$ \\
\hline V-126 (V-10110) & KAUZ/CMH77A-308//BAU/3/INQ-91 & 0 & 40MSS \\
\hline V-130 & KANZU & ;1- & $60 \mathrm{MSS}$ \\
\hline V-11172 & KANCHAN//INQALAB91*2/KUKUNA & $0 / 3+$ & $60 \mathrm{M}$ \\
\hline V-12001 & WAXWING/4/SNI/TRAP\#1/3/KAUZ*2/TRAP//KAUZ & $0 / 3$ & $40 \mathrm{M}$ \\
\hline CCRI-12 & LIS “S”/KVZ/TRM//PTM/ANA X UP262 & 0 & $50 \mathrm{M}$ \\
\hline CCRI-13 & F-3-71/TRM X F. SARHAD & 2 & $30 \mathrm{M}$ \\
\hline CCRI-16 & CANDIAN/CUNNINGHAM//KENNEDY & 23 & $60 \mathrm{MSS}$ \\
\hline
\end{tabular}

Table 5. Narrative of baseline resistance study (BRS) sets screened for Puccinia graminis f. sp. tritici at the seedling and adult plant stages.

\begin{tabular}{lccc}
\hline Year & BRS designation & Total number of lines & $\begin{array}{c}\text { No. of contributing institutes in } \\
\text { Pakistan }\end{array}$ \\
\hline $2010-11$ & $1^{\text {st }}$ BRS & 195 & 9 \\
$2011-12$ & $2^{\text {nd }}$ BRS & 271 & 8 \\
$2012-13$ & $3^{\text {rd }}$ BRS & 241 & 19 \\
\hline
\end{tabular}

not shown). Adult plant resistance was exhibited by 101 lines with diverse field reactions (MS to RMR) and disease severities ranging from 5 to $40 \%$, based on the modified Cobb scale (Table 3). All of these lines displayed seedling susceptibility (IT $33+$ to 4 ), implying the presence of APR. Four entries (Sandal, DH-31, NIA-MN-8 and AZRC-12) displayed MR, with disease severities reaching $40 \%$. Moderate responses (M or MRMS) were observed for most lines that displayed a severity of up to $30 \%$. Resistant-tomoderately resistant responses and disease severities of up to $20 \%$ were observed for lines NR-405, SD-5, V-117, AZRC16 and AZRC-17 (Table 3). These lines are the most desirable ones for use in breeding for durable resistance to stem rust. Previous research emphasized that lines showing seedling susceptibility but adult plant resistance to Ug99 in the field can be useful sources of Ug99 resistance (Nazari et al., 2008; Rouse et al., 2011; Singh et al., 2008). There were lines that showed resistance at seedling stage but were moderate susceptible in the field at the adult stage (Table 4). This type of response could be attributed either to major gene(s) operating only at the seedling stage, weather factors or disease/inoculum pressure in the field (Hickey et al., 2012). Understanding the resistance in these lines could facilitate their better use in breeding for stem rust resistance, possibly 
leading gene combinations for resistance against multiple Pgt races.

During the three years of study reported, the outcomedriven science collaboration under the Wheat Production Enhancement Program for Pakistan (WPEP) increased the frequency of stem rust resistance in Pakistan's national breeding programs. In 2010, only $15 \%$ of Pakistani wheat germplasm was resistant to Ug99 (TTKSK), but the number increased to $49 \%$ in 2012-13. The resistant germplasm provided national partners a range of sources of stem rust resistance and the associated knowledge to increase genetic gains for stem rust resistance in their breeding programs, with the release of two Ug99 resistant varieties NARC-2011 and Pak-2013 and a number of candidate in the pipeline.

\section{Materials and methods}

\section{Experimental materials}

Baseline resistance study (BRS) sets were prepared by collecting advanced spring wheat breeding lines and varieties from national wheat breeding programs across Pakistan. Three sets designated as 1BRS, 2BRS and 3BRS and having 195, 271 and 241 entries were assembled during 2010-11, 2011-12 and 2012-13, respectively, and used for this study (Table 5). These sets comprised old and newlyreleased wheat varieties and advanced lines, as well as germplasm introduced to Pakistan from CIMMYT.

\section{Pgt races used in seedling and field evaluation}

All the lines were tested for seedling resistance at the cereal disease laboratory, University of Minnesota-St. Paul, using the eastern African Pgt race (TTKSK = Ug99). Lines that were initially resistant to race TTKSK were further screened against the variant TTKST. The seedlings were fertilized at emergence stage with 20-20-20 liquid fertilizer and shifted to a clean (rust free) glass house until inoculation. Briefly, seedlings were inoculated when plants fully expanded primary leaves (7-9 days of sowing) with urediniospores of stem rust isolates suspended in mineral oil $(\sim 5.0 \mathrm{mg}$ of rust in $0.8 \mathrm{ml}$ oil). After inoculation, plants were dried for $\sim 10$ minutes and shifted to dew chamber for 14-16 hours in darkness at $18-21^{\circ} \mathrm{C}$ temperature and $100 \%$ relative humidity. Next day plants were slowly dried and exposed to fluorescent lights for 4 hours. After dew period, plants were moved to a dew chamber at $18-22^{\circ} \mathrm{C}$ and 16 hours of light for 6 days and were scored on the $14^{\text {th }}$ day after inoculation. For field evaluation spreader rows were planted perpendicularly and around the experimental plots and also inoculated with a bulk collection of Ug99 TTKSK and TTKST with added virulence to $\mathrm{Sr} 24$ to create an artificial disease epidemic. Urediniospores were collected from inoculum increase plots planted with wheat varieties possessing both Sr31 and Sr24, which are expected to select for Pgt race TTKST, the Ug99 variant with virulence to both Sr31 and Sr24 (Njau et al., 2012).

\section{Seedling evaluation}

For seedling evaluation five to six untreated seeds of each variety/line were planted in pots at a depth of $1 \mathrm{~cm}$, along with seeds of susceptible control McNair701 during 2010-11 (1BRS), 2011-12 (2BRS) and 2012-13 (3BRS). Procedures for inoculation and disease assessment followed Jin et al. (2007). Plants were scored on the $14^{\text {th }}$ day after inoculation using a 0-4 Stakman et al. (1962) scale. Infection types 0-2++ were considered low, indicating host resistance, while ITs 34 were considered high, indicating host susceptibility. When low and high ITs were present on the same leaf, the plant was considered resistant. Lines were classified as heterogeneous when both resistant and susceptible plants were present.

\section{Field evaluation}

Wheat lines were sown in double rows on plots $1 \mathrm{~m}$ in length for field screening at the wheat research institute facility of Kenya Agricultural and Livestock Research Organization (KALRO) in Njoro, Kenya, during 2010-11, 201112 and 2012-13. Lines were scored at the soft dough stage for stem rust severity on a scale of $0-100 \%$ stem area affected using the modified Cobb scale (Peterson et al., 1948). Infection response was scored using categorical scores based on the size of the stem rust pustules and the amount of associated chlorosis and necrosis. Infection response categories included the following, either singly or in combination: resistant (R), moderately resistant (MR), intermediate (M), moderately susceptible (MS), and susceptible (S) (Nzuve et al., 2012). Combinations of categories were recorded when two distinctly different infection responses occurred on a single stem (i.e., MR-MS ratings indicated MR pustules on the same stem as MS pustules). The predominant category was listed first, such that MR-MS differed from MS-MR. When lines with different infection responses or severities on the same plant were observed, a comma (,) was used to separate the readings.

\section{DNA marker analysis}

The three BRS sets were screened with a ' $G b^{\prime}$ ' molecular marker linked to Sr25/Lr19 (Prins et al., 2001) at the USDAARS Eastern Regional Genotyping Laboratory, Raleigh, NC. Methods for genotyping followed Olson et al. (2010).

\section{Acknowledgment}

This work was supported by the United States Department of Agriculture (USDA) through funding of Wheat Production Enhancement Program (WPEP) for Pakistan. We are grateful to Mike Listman for text editing.

\section{References}

Bhavani S, Singh RP, Argillier O, Huerta-Espino J, Singh S, Njau P (2011) Mapping of durable adult plant stem rust resistance in six CIMMYT wheats to Ug99 group of races. Paper presented at Borlaug Global Rust Initiative technical workshop, St. Paul, Minnesota, 13-16 June 2011.

Hare RA, McIntosh RA (1979) Genetic and cytogenetic analysis of durable adult plant resistance in Hope and related cultivars to wheat rusts. Zeitschrift für Pflanzenzüchtung. 83:350-367.

Herrera-Foessel SA, Singh RP, Lilemo M, Huerta-Espino J, Bhavani S, Singh S, Lan C, Calvo-Salazar V, Lagudah ES (2014) Lr67/Yr46 confers adult plant resistance to stem rust and powdery mildew in wheat. Theor Appl Genet. 127:781-789.

Hickey LT, Wilkinson PM, Knight CR, Godwin ID, Kravchuk OY, Aitken EAB, Bansal UK, Bariana HS, Lacy IHD, Diet MJ (2012) 
Rapid phenotyping for adult-plant resistance to stripe rust in wheat. Plant Breed. 131(1):54-61.

Jin Y, Singh RP (2006) Resistance in U.S. wheat to recent eastern african isolates of Puccinia graminis $\mathrm{f}$. $\mathrm{sp}$. tritici with virulence to resistance gene Sr31. Plant Dis. 90:476-480.

Jin $Y$, Singh RP, Ward R, Wanyera R, Kinyua M, Njau P, Fetch T, Pretorius ZA, Yahyaoui A (2007) Characterization of seedling infection types and adult plant infection responses of monogenic $S r$ gene lines to race TTKS of Puccinia graminis $f$. sp. tritici. Plant Dis. 91:1096-1099.

Jin Y, Szabo LJ, Pretorius ZA, Singh RP, Ward R, Fetch T Jr (2008) Detection of virulence to resistance gene $S r 24$ with in race TTKS of Puccinia graminis f. sp. tritici. Plant Dis. 92:923-926.

Jin $Y$, Szabo L, Rouse MN, Fetch Jr T, Pretorius ZA, Wanyera R, Njau P (2009) Detection of virulence to resistance gene Sr36 within the TTKS race lineage of Puccinia graminis $\mathrm{f}$. $\mathrm{sp}$. tritici. Plant Dis. 93:367-370.

Kumssa TT, Baenziger PS, Rouse MN, Guttieri M, Dweikat I, Brown-Guedira G, Williamson S, Graybosch RA, Wegulo SN, Lorenz AJ, Poland J (2015) Characterization of stem rust resistance in wheat cultivar Gage. Crop Sci. 55:229-239.

Nazari K, Amini A, Yahyaoui A, Singh R (2008) Characterization of seedling and adult-plant resistance to stem rust race Ug99 in Iranian bread wheat landraces. Paper presented at the proceedings of the $11^{\text {th }}$ International Wheat Genetics Symposium, Brisbane, Australia 24-29 August 2008.

Nazari K, Mafi M, Yahyaoui A, Singh RP, Park RF (2009) Detection of wheat stem rust (Puccinia graminis f. sp. tritici) race TTKSK (Ug99) in Iran. Plant Dis. 93(3):317.

Newcomb M, Olivera PD, Rouse MN, Szabo LJ, Johnson J, Gale S, Luster DG, Wanyera R, Macharia G, Bhavani S, Hodson D, Patpour M, Hovmoller MS, Fetch TG Jr, Jin Y (2016) Kenyan isolates of Puccinia graminis f. sp. tritici from 2008 to 2014: Virulence to SrTmp in the Ug99 race group and implications for breeding programs. Phytopathology. 106:729-736.

Njau P, Jin Y, Huerta-Espino J, Keller B, Singh R (2010) Identification and evaluation of sources of resistance to stem rust race Ug99 in wheat. Plant Dis. 94:413-419.

Njau PN, Bhavani S, Huerta-Espino J, Keller B, Singh RP (2012) Identification of QTL associated with durable adult plant resistance to stem rust race Ug99 in wheat cultivar 'Pavon 76'. Euphytica. 190:33-44.

Nzuve FM, Bhavani S, Tusiime G, Njau P, Wanyera R (2012) Evaluation of bread wheat for both seedling and adult plant resistance to stem rust. Afr J Plant Sci. 6(15):426-432.

Olson EL, Brown-Guedira G, Marshall DS, Jin Y, Mergoum M, Lowe I, Dubcovsky J (2010) Genotyping of U.S. wheat germplasm for presence of stem rust resistance genes Sr24, Sr36, and Sr1RSAmigo. Crop Sci. 50:668-675.

Patpour M, Hovmoller MS, Newcomb M, Olivera P, Jin Y, Luster D, Hodson D, Nazari K, Shahin AA, Azab M (2016) First report of the Ug99 race group of wheat stem rust, Puccinia graminis f. sp. tritici, in Egypt. Plant Dis. 100:863.

Peterson RF, Campbell AR, Hannah AE (1948) A diagrammatic scale for estimating rust intensity of leaves and stem of cereals. Can J Res. 26:496-500.

Pretorius ZA, Singh RP, Wagoire WW, Payne TS (2000) Detection of virulence to wheat stem rust resistance gene Sr31 in Puccinia graminis f. sp. tritici in Uganda. Plant Dis. 84(2):203.

Pretorius ZA, Bender CM, Visser B, Terefe T (2010) First report of a Puccinia graminis $\mathrm{f}$. sp. tritici race virulent to the Sr24 and Sr31 wheat stem rust resistance genes in South Africa. Plant Dis. 94(6):784.

Prins R, Groenewald JZ, Marais GF, Snape JW, Koebner RMD (2001) AFLP and STS tagging of Lr19, a gene conferring resistance to leaf rust in wheat. Theor Appl Genet. 103:618624.
Rosewarne GM, Singh RP, Huerta-Espino J, William HM, Bouchet $\mathrm{S}$, McFadden H, Lagudah ES (2006) Leaf tip necrosis, molecular markers and B1-proteasome subunits associated with the slow rusting resistance genes $L r 46 / Y r 29$. Theor Appl Genet. 112:500-508.

Rouse MN, Wanyera R, Njau P, Jin Y (2011) Sources of resistance to stem rust race Ug99 in spring wheat germplasm. Plant Dis. 95:762-766.

Rubiales D, Nicks RE (2000) Combination of mechanism of resistance to rust fungi as a strategy to increase durability. Options Mediterr. 333-339.

Singh RP (1992) Association between gene Lr34 for leaf rust resistance and leaf tip necrosis in wheat. Crop Sci. 32:874-878.

Singh RP, Huerta-Espino J, Rajaram S (2000) Achieving nearimmunity to leaf and stripe rusts in wheat by combining slow rusting resistance genes. Acta Phytopathol Hun. 35:133-139.

Singh RP, William HM, Huerta-Espino J, Rosewarne G (2004) Wheat rust in Asia: Meeting the challenges with old and new technologies. Paper presented at "New directions for a diverse planet". Proceedings of the $4^{\text {th }}$ international crop science congress, Brisbane, Australia, 26 Sep-1 Oct 2004.

Singh RP, Huerta-Espino J, William HM (2005) Genetics and breeding of durable resistance to leaf and stripe rusts in wheat. Turk J Agric For. 29:121-127.

Singh RP, Hodson DP, Jin Y, Huerta-Espino J, Kinyua MG, Wanyera R, Njau P, Ward R (2006) Current status, likely migration and strategies to mitigate the threat to wheat production from race Ug99 (TTKS) of stem rust pathogen. CAB Reviews: Perspectives in Agriculture, Veterinary Science, Nutrition and Natural Resources. 1(54):1-13.

Singh RP, Hodson DP, Huerta-Espino J, Jin Y, Njau P, Wanyera R, Herrera-Foessel SA, Ward R (2008) Will stem rust destroy the world's wheat crop? Adv Agron. 98:271-309

Singh RP, Huerta-Espino J, Bhavani S, Singh D, Singh PK, HerreraFoessel SA, Njau P, Wanyera R, Jin Y (2009) Breeding for minor gene-based adult plant resistance to stem rust in wheat. Paper presented at Borlaug Global Rust Initiative technical workshop, Cd. Obregon, Sonora, Mexico, 17-20 March 2009.

Singh RP, Hodson DP, Huerta-Espino J, Jin Y, Bhavani S, Njau P, Herrera-Foessel SA, Singh PK, Singh S, Govindan V (2011) The emergence of Ug99 races of the stem rust fungus is a threat to world wheat production. Annu Rev Phytopathol. 49:465481.

Singh RP, Rajaram S (1992) Genetics of adult plant resistance of leaf rust in 'Frontana' and three CIMMYT wheat. Genome. 35:24-31.

Stakman EC, Stewart DM, Loegering WQ (1962) Identification of physiologic races of Puccinia graminis var. tritici. Agricultural Research Service E 617, USDA, Washington DC, USA.

Wanyera R, Kinyua MG, Jin Y, Singh R (2006) The spread of Puccinia graminis $\mathrm{f}$. sp. tritici with virulence on Sr31 in Eastern Africa. Plant Dis. 90:113. 